\title{
Diamond nanocrystals with nitrogen-vacancy centers as new type temperature sensors
}

\author{
Nanokryształy diamentu z centrami barwnymi azot-wakancja \\ jako czujniki temperatury nowego typu
}

\author{
DANIEL S. RUDNICKI \\ MARIUSZ MRÓZEK \\ WOJCIECH GAWLIK \\ KRZYSZTOF WOJCIECHOWSKI *
}

\author{
DOI: 10.17814/mechanik.2016.5-6.69 \\ Międzynarodowa Konferencja IMT 2016
}

\begin{abstract}
Nitrogen vacancy color centers in diamond (NVs) as a new type of temperature sensors were presented in the article. Recent progress in the field of NV thermometry and summarize the techniques of NVs manufacturing was briefly discussed. The use of NVs for characterization of thermoelectric materials was proposed.
\end{abstract}

KEYWORDS: nitrogen-vacancy, NV, thermometry, thermoelectrics, nanodiamonds

W artykule zaprezentowano centra barwne azot-wakancja (NV) w diamentach w roli czujnika temperatury nowego typu. Krótko omówiono ostatnie doniesienia naukowe oraz podsumowano techniki wytwarzania diamentów z centrami NV. Zaproponowano nowatorskie wykorzystanie centrów NV do badania materiałów termoelektrycznych

SŁOWA KLUCZOWE: azot-wakancja, NV, termometria, termoelektryki, nanodiamenty

\section{Modern thermometry}

Many methods have been developed for measuring temperature. Among the most important challenges remaining in the thermometry field are high-sensitivity measurements with a sub-micrometer spatial resolution. The development of precise micro-/nanoscale temperature measurements is important in many research fields [1]. It might be very useful e.g. to track and control intracellular processes in biology/medicine [2], chemical reactions [1] and/or quality of the new materials (e.g. thermoelectrics or semiconductors). These issues motivate a demand for new sensors and drive the progress in the field. Examples of the new developments are scanning thermal microscopes [3], dispersed or scanned fluorescent nanoprobes $[4,5]$, and Raman spectroscopes [6]. Despite many novel techniques, precise nanoscale temperature measurements have not been realized so far. The nitrogen-vacancy (NV) center in diamond is a promising candidate to fill this gap.

\section{Diamond with NV center as a temperature sensor}

Diamond crystals are known for high hardness and chemical inertness. Thanks to the superb thermal conductivity, diamond is also an ideal material to host a temperature

\footnotetext{
* Mgr inż. Daniel S. Rudnicki (rudnicki@agh.edu.pl) - Wydział Inżynierii Materiałowej i Ceramiki, Akademia Górniczo-Hutnicza i Instytut Fizyki, Uniwersytet Jagielloński; mgr Mariusz Mrózek, prof. dr hab. Wojciech Gawlik - Instytut Fizyki, Uniwersytet Jagielloński; prof. dr hab. inż. Krzysztof Wojciechowski - Wydział Inżynierii Materiałowej i Ceramiki, Akademia Górniczo-Hutnicza
}

sensor. In this paper the nitrogen-vacancy color centers are introduced [7]. These extraordinary objects are used as sensors in different fields, like quantum information processing [8], magnetometry [9], optical tracking [2] and thermometry [1]. The NV center may be incorporated into nanodiamonds (NDs) and serve as a thermometric sensor, which might be localized with a nanometer resolution [1]. Moreover, nanodiamonds are biocompatible and might be introduced and tracked within living cells [2]. The sensing is performed optically in an non-contact and non-destructive way. The sensitivity of such sensors could potentially reach $1 \mathrm{mK}$ [10]. They can be used for temperature measurements up to about $600 \mathrm{~K}$.

The NV center consists of a substitutional-nitrogen atom and an adjacent lattice vacancy. The electronic structure of the center contains two triplet levels (spin equal to 1 ) split by $1.945 \mathrm{eV}$, which lie within the diamond electronic band gap. The optical excitation of the center with a green light results in a strong and stable red fluorescence [11] (see figure). In room-temperature the ground-state sublevels are equally populated. The green-light illumination causes the NVs to preferentially populate the $m_{s}=0$ sublevel [12]. By the application of a microwave (MW) field one can then induce the magnetic resonance. Since the intensity of the red fluorescence depends on the population distribution within the ground state, the magnetic resonance can be observed optically as variations of the luminescence intensity. The technique is called optically detected magnetic resonance (ODMR).

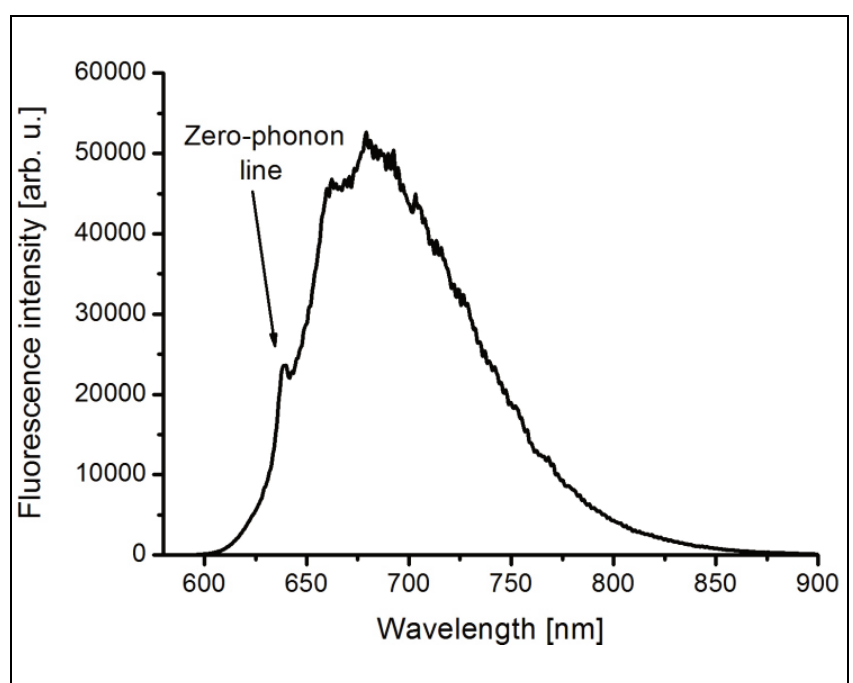

Fluorescence spectrum of the $\mathrm{NV}^{-}$illuminated by green light $(532 \mathrm{~nm})$. Zero-phonon line indicates the optical transition at $637 \mathrm{~nm}$, which does not induce phonons 
Close to the room temperature, the resonance frequency $D_{g}$ depends on the temperature $T$ of the crystal as [13]:

$$
\mathrm{d} D_{\mathrm{g}} / \mathrm{d} T=-74.3 \mathrm{kHz} / \mathrm{K}
$$

By monitoring the changes of $D_{g}$ one can measure the temperature of the diamond crystal and its environment. The measurement sensitivity depends on the ODMR linewidth and the signal magnitude. These values are limited by the NV coherence time $\left(T_{2}\right)$ and the number of centers used as sensors, respectively. The ideal diamond temperature sensor should contain close to $500 \mathrm{NVs}$ with the $T_{2}$ not less than $1 \mathrm{~ms}$ [14] (the longer the better).

In the recent years several groups have presented temperature measurements using NV centers. Toyli et al. have shown in [15] that with special protocols preserving the NV's coherence, the sensitivity approaching $10 \mathrm{mK} \mathrm{Hz}^{-1 / 2}$ is achievable for single centers. Neumann et al. recorded a temperature noise floor of $5 \mathrm{mK} \mathrm{Hz}^{-1 / 2}$ for single NVs in a bulk, which results in the accuracy of about $1 \mathrm{mK}$ [10]. In the same work $130 \mathrm{mK} \mathrm{Hz}^{-1 / 2}$ was measured for few tens of nanometers diamond containing NV centers.

The measurements with microwaves require a way to deliver MW power to the crystal, not trivial in the case of intracellular measurements. Recently, Plakhotnik et al. proposed an all-optical thermometry using NV centers in nanodiamonds [14] which eliminates the MWs. The idea is to measure the ratio between the components of the optical spectra in the visible range. For an ideal diamond containing $500 \mathrm{NVs}$ the noise floor is predicted at $100 \mathrm{mK} \mathrm{Hz}^{-1 / 2}$ level. This value is higher than in an ideal case with the ODMR technique, but the fabrication of ideal nanodiamonds with still remains a challenge. The proposed technique is much simpler, does not require microwaves, and might be implemented readily using commercial spectral-resolving imaging systems.

\section{The manufacturing of diamond containing NV centers}

To create efficient sensors one has to optimize the technique of producing ideal nanodiamonds with NVs. The two main techniques of diamond manufacturing are typically used, the high pressure-high temperature (HPHT) and the chemical vapour deposition (CVD). The ideal sensor should contain about $500 \mathrm{NVs}$ [14], hosted in a nanocrystal of ultrapure diamond below $100 \mathrm{~nm}$ size. Creation of fluorescent nanodiamonds (fNDs) presents several difficulties since the nanocrystals should be strain-less and defects-free but with high-NV concentration. In one of the first successful proposals [16] fNDs were produced from commercial microdiamonds (HPHT type), which were subsequently irradiated by $\mathrm{e}^{-}$beam and annealed for 2 hours in $800^{\circ} \mathrm{C}$. Next, the crystallites were milled and washed in the $\mathrm{HNO}_{3} / \mathrm{HF}$. In that way, $15 \%$ of the original mass was transformed to the powder below $10 \mathrm{~nm}$ size. The more recent approach with irradiation in aqueous colloidal solution [17] increased the fNDs fraction but the ideal way of production of fNDs remains as a serious challenge.

\section{Using nanodiamonds for a characterization of new ma- terials}

The fND might be used to study new thermoelectric materials e.g. by observing processes on the surface (e.g. on the grain boundaries). Coating a surface of a new material with a ND powder will enable a non-contact all-optical thermometry with high spatial resolution. It would be a new convenient method of characterization of novel materials.
The project has been partially supported by the National Centre of Science project No. 2013/09/B/ST8/02043

\section{LITERATURE}

1. Sokolov K. „Tiny thermometers used in living cells”. Nature. Vol. 500, No. 7460 (2013): pp. 36 $\div 37$.

2. Fu C.-C., Lee H.-Y., Chen K., Lim T.-S., Wu H.-Y., Lin P.-K., Wei P.-K., Tsao P.-H., Chang H.-C., Fann W. „Characterization and application of single fluorescent nanodiamonds as cellular biomarkers". Proc. Natl. Acad. Sci. USA. Vol. 104, No. 3 (2007): pp. $727 \div 732$

3. Majumdar A. „Scanning thermal microscopy”. Annu. Rev. Mater. Sci. Vol. 29 (1999): pp. 505:585.

4. Vetrone F., Naccache R., Zamarrón A., Juarranz de la Fuente A., Sanz-Rodríguez F., Martinez Maestro L., Martín Rodriguez E., Jaque D., García Solé J., Capobianco J.A. „Temperature sensing using fluorescent nanothermometers". ACS Nano. Vol. 4, No. 6 (2010): pp. 3254:3258.

5. Okabe K., Inada N., Gota C., Harada Y., Funatsu T., Uchiyama S., "Intracellular temperature mapping with a fluorescent polymeric thermometer and fluorescence lifetime imaging microscopy". Nat. Commun. No. 3 (2012): p. 705

6. Beechem T., Graham S., Kearney S.P., Phinney L.M., Serrano J.R. "Simultaneous mapping of temperature and stress in microdevices using micro-Raman spectroscopy". Rev. Sci. Instrum. Vol. 78, No. 6 (2007): pp. 61301 $\div 061301-9$.

7. Bradac C., Gaebel T., Rabeau J. R. Optical Engineering of Diamond (Eds. R. P. Mildren and J. R. Rabeau), Weinheim Wiley-VCH Verlag GmbH \& Co. KGaA, 2013.

8. Neumann P., Kolesov R., Naydenov B., Beck J., Rempp F., Steiner M., Jacques V., Balasubramanian G., Markham M. L., Twitchen D. J., Pezzagna S., Meijer J., Twamley J., Jelezko F., Wrachtrup J. „Quantum register based on coupled electron spins in a roomtemperature solid". Nature Phys. Vol. 6 (2010): pp. 249 $\div 253$

9. Taylor J.M., Cappellaro P., Childress L., Jiang L., Budker D., Hemmer P.R., Yacoby A., Walsworth R., Lukin M.D. „High sensitivity diamond magnetometer witch nanoscale resolution". Nature Phys. Vol. 4, (2008): pp. 810 $\div 816$.

10. Neumann P., Jakobi I., Dolde F., Burk C., Reuter R., Waldherr, Honert J., Wolf T., Brunner A., Shim J.H., Suter D., Sumiya H., Isoya J, Wrachtrup J. „High-precision nanoscale temperature sensing using single defects in diamond". Nano Lett. Vol. 13 (2013): pp. $2738 \div 2742$.

11. Preez L. [du], PhD thesis, Johannesburg: University of Witwatersrand, 1965

12. Harrison J., Sellars M.J., Manson N.B. „Nitrogen-vacancy center in diamond: Model of the electronic structure and associated dynamics". Phys. Rev. B. Vol. 74, No.10 (2006): p. 104303.

13. Acosta V.M, Bauch E., Ledbetter M.P., Waxman A., Bouchard L.-S., Budker D. „Temperature Dependence of the Nitrogen-Vacancy Magnetic Resonance in Diamond". Phys. Rev. Lett. Vol. 104 (2010): p. 070801.

14. Plakhotnik T., Doherty M.W., Cole J.H., Chapman R., Manson N.B., „All-optical thermometry and thermal properties of the optically detected spin resonance of the NV center in nanodiamond". Nano

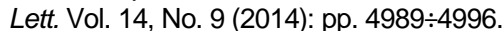

15. Toyli D.M., de las Casas C.F., Christle D.J., Dobrovitski V.V., Awschalom D.D. „Fluorescent thermometry enhanced by the quantum coherence of single spins in diamond". Proceedings of the National Academy of Sciences of the USA. Vol. 110, No. 21 (2013): pp. $8417 \div 8421$.

16. Boudou J-P., Curmi P.A., Jelezko F., Wrachtrup J., Aubert P., Sennour M., Balasubramanian G., Reuter R., Thorel A. Gaffet E. "High yield fabrication of fluorescent nanodiamonds". Nanotechnology. Vol. 20, No. 23 (2009): p. 235602.

17. Stursa J., Havlik J., Petrakova V., Gulka M., Ralis J., Zach V., Pulec Z., Stepan V., Zargalech S.A., Ledvina M., Nesladek M., Treussart F., Cigler P. „Mass production of fluorescent nanodiamonds with narrow emission intensity distribution". Carbon. Vol. 96 (2016): pp. $812 \div 818$ 